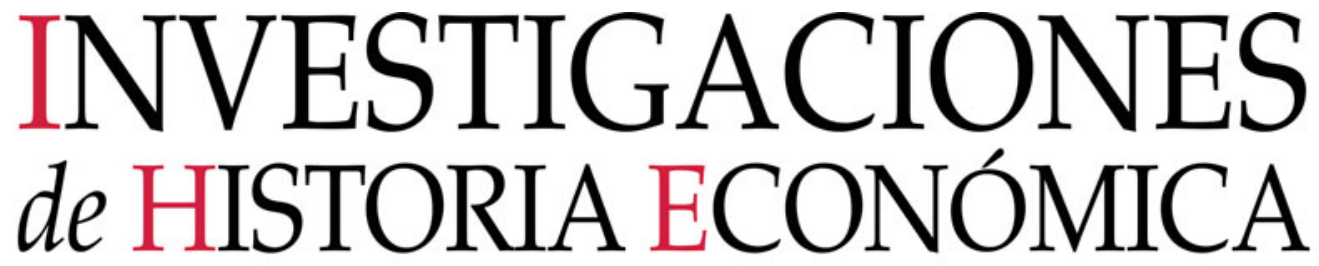

VOLUMEN $15 \cdot$ NÚMERO 2 • Junio 2019

\title{
Economic History Research
}

\section{artículos}

JOSÉ M. MENUDO Y JOSÉ M. ${ }^{a}$ O'KEAN

El mercado de empresarios en la historia del pensamiento económico. Historia de un fracaso

\section{EMILIO PÉREZ ROMERO}

Precios, salarios y carga laboral durante el siglo XVIII. El caso de la villa de El Burgo de Osma (Soria)

\section{PALOMA FERNÁNDEZ PÉREZ}

Y FERRAN SABATÉ CASELLAS

Entrepreneurship and management in the therapeutic revolution: The modernisation of laboratories and hospitals in Barcelona, 1880-1960

JUAN MANUEL MATÉS-BARCO Y LUIS GONZÁLEZ-RUIZ La actividad inversora del Banco de Crédito Local de España en su primera época (1925-1936)

\section{VITTORIO DANIELE Y RENATO GHEZZI}

The impact of World War II on nutrition and children's health in Italy

\section{reseñas}




\section{SUBMISSION INFORMATION FOR CONTRIBUTORS}

\section{Editorial Policy}

RHE-JILAEH publishes original research papers on economic history, and related fields in the social sciences. RHE-JILAEH publishes articles with a specific, but not exclusive, focus on economic history in Iberia and Latin America. The journal has a broad chronological coverage from pre-modern and colonial times to contemporary issues and welcomes contributions with comparative approaches and long-term analysis.

Papers should be original and should be neither published nor be under consideration for publication elsewhere. RHE-JILAEH accepts manuscripts for consideration in Spanish, English and Portuguese, though will only publish in either Spanish or English.

Evaluation process and publication times. RHE-JILAEH publishes three issues yearly (spring, autumn and winter) with Numbers 1,2 and 3 being published before the end of March, September and December respectively each year. The editors will make every attempt to be rigorous and transparent throughout the evaluation process from the initial receipt of the manuscript to its final acceptance; details of the review process are available on the website rhe-jilaeh.com. We also make a commitment to reduce the time between acceptance of an article and its publication as far as possible.

\section{Submission of manuscripts.}

Manuscripts must be submitted online via the ScholarOne submission system (http://mc.manuscriptcentral.com/ rhe-jilaeh) in a Microsoft Word file format. Graphs, tables and maps which cannot be included in the file may be submitted in an additional Excel file via the same platform. Any questions related to submission should be directed to the editorial office by email (rhe@uc3m.es).

Editorial contact:

Prof. Blanca Sanchez-Alonso (rhe@uc3m.es, blanca@ceu.es)

Format of submission. Manuscripts are to be submitted double-spaced. The text length should not exceed 12,000 words, including footnotes, references and appendix, if any, but excluding tables and figures. In the case of very long appendices the journal reserves the right to publish them online only.

Full guidelines. For full information for contributors, please consult

https://www.cambridge.org/core/journals/ revista-de-historia-economica-journal-ofiberian-and-latin-american-economic-history and http://rhe-jilaeh.com/en.

Journal Citation Report 2018 impact factor is 0.710 . This journal is also included in Econ-Lit, Scopus, RePEc, EBSCOhost, Latindex, Cabell's, HA, IBSS and CINDOC-ISOC.

\section{NORMAS DE ENVÍO PARA LOS AUTORES}

\section{Línea editorial}

RHE-JILAEH publica artículos originales de investigación sobre historia económica y disciplinas relacionadas dentro de las ciencias sociales. El ámbito geográfico de sus artículos lo constituyen de forma preferente, pero no exclusiva, la Península Ibérica y América Latina. La Revista cubre cronológicamente un periodo amplio, desde la edad moderna y colonial hasta temas contemporáneos, y valora especialmente los trabajos comparativos y los análisis de largo plazo. RHE-JILAEH publica artículos en inglés y en español.

Los trabajos que se envíen a la Revista han de ser originales, no publicados ni sometidos a consideración para su publicación en otro medio. Los manuscritos pueden ser enviados en español, inglés o portugués, aunque serán publicados sólo en español o en inglés.

Proceso de evaluación y tiempos de publicación. RHE-JILAEH publica tres números al año (primavera, otoño e invierno). Los Números 1, 2 y 3 se publican antes de finales de marzo, septiembre y diciembre de cada año respectivamente. Los editores se proponen ser rigurosos y transparentes en el proceso de revisión haciendo explícito el protocolo de evaluación desde el acuse de recibo hasta la aceptación final; se pueden consultar los detalles en la web rhe-jilaeh.com (ver Proceso de Revisión). Los editores se comprometen a ser razonablemente expeditivos entre la aceptación del manuscrito y su publicación.

Envío de originales: Los manuscritos deben ser enviados online utilizando la plataforma ScholarOne (http:// mc.manuscriptcentral.com/rhe-jilaeh) en un documento de Microsoft Word. Los gráficos, cuadros y mapas que no se puedan incluir en este archivo deberán ser enviados a través de la misma plataforma en un archivo Excel.

Cualquier pregunta relacionada con el envío de originales deberá dirigirse al correo electrónico de la oficina editorial (rhe@uc3m.es).

Contacto editorial:

Prof.Blanca Sánchez-Alonso (rhe@uc3m.es, blanca@ceu.es)

Formato. Los originales deberán ir escritos a doble espacio. La extensión total no superará las $\mathbf{1 2 . 0 0 0}$ palabras, incluidas notas a pie de página, bibliografia y apéndices en su caso, pero sin contar gráficos y cuadros. En el supuesto de apéndices muy extensos la Revista se reserva la posibilidad de publicar estos únicamente online.

Instrucciones completas. Para acceder a la información completa se puede consultar https://www.cambridge.org/core/journals/ revista-de-historia-economica-journal-of-iberianand-latin-american-economic-history y http://rhe-jilaeh.com

El índice de impacto de 2018 del Journal Citation Report es 0,710. La Revista también está incluida en Econ-Lit, Scopus, RePEc, EBSCOhost, Latindex, Cabell's, HA, IBSS and CINDOC-ISOC. 


\section{Mission Statement}

The Revista de Historia Económica - Journal of Iberian and Latin American Economic History (RHE-JILAEH) provides a global forum for original and innovative research on economic history and related fields from the different social sciences. RHE-JILAEH publishes original research articles with a specific, but not exclusive, focus in Iberia and Latin America economic history. The journal has a broad chronological coverage since pre-modern and colonial times to contemporary issues and welcomes contributions with comparative approaches and long-term analysis. RHE-JILAEH publishes articles in English and Spanish.

\section{Declaración de objetivos}

La Revista de Historia Económica - Journal of Iberian and Latin American Economic History (RHE-JILAEH) proporciona un foro global para la investigación innovadora y original en historia económica y otras disciplinas afines de las ciencias sociales. RHE-JILAEH publica artículos de investigación original con una orientación prioritaria, pero no exclusiva, en la historia económica de la Península Ibérica y de América Latina. La Revista tiene un enfoque cronológico amplio desde la era medieval, moderna y el periodo colonial hasta la edad contemporánea y da la bienvenida a trabajos con enfoques comparativos y análisis de largo plazo. RHE-JILAEH publica artículos en inglés y en castellano. 